\title{
Reproductive apparatus and gametogenesis of Lophiosilurus alexandri Steindachner (Pisces, Teleostei, Siluriformes)
}

\author{
Marcelo D. M. Barros; Rodrigo J. Guimarães-Cruz; Vanderlei C. Veloso-Júnior \& José E. dos Santos
}

Programa de Pós-graduação em Zoologia de Vertebrados, Pontifícia Universidade Católica de M inas Gerais. Avenida Dom José Gaspar 500, Coração Eucarístico, 30535-610 Belo Horizonte, M inas Gerais, Brasil. E-mail: enemir@pucminas.br

\begin{abstract}
The gonad morphology and gametogenesis of Lophiosilurus alexandri Steindachner, 1877 from Santo Antônio river (Minas Gerais, Brazil) were studied through anatomical and histological techniques. Examination of the testis revealed that they were paired, fringed organs with two distinct regions: cranial spermatogenic and caudal spermatogenic and secretory. The cranial region represents ca. $60 \%$ of the mature/maturing testis, containing 41 to 73 fringes, while the caudal portion represents ca. $40 \%$ and contains 44 to 68 fringes. At the cranial portion the length of the fringes was $3.70 \pm 1.70 \mathrm{~mm}$ and in the caudal portion was $0.20 \pm 0.10 \mathrm{~mm}$. The spermatogenesis was cystic, synchronic, and occurred throughout the whole extension of the seminiferous tubules. The ovaries were saculiforms, paired organs, which present ovigerous lamellae containing cells of the oogenic lineage. The oocytes were classified into four developmental stages according to their cytological characteristics and the characteristics of the cell layers that surround them.

KEY WORDS. Gonads; morphology; oogenesis; Pseudopimelodidae; spermatogenesis.

RESUMO. Aparelho reprodutor e gametogênese de Lophiosilurus alexandri Steindachner (Pisces, Teleostei, Siluriformes). A morfologia das gônadas e a gametogênese de Lophiosilurus alexandri Steindachner, 1877 do rio Santo Antônio, bacia do rio Doce, Minas Gerais, foram estudadas através de técnicas anatômicas e histológicas. Os testículos são órgãos pares, franjados e apresentam regiões cranial espermatogênica e caudal espermatogênica e secretora. A região cranial corresponde aproximadamente a $60 \%$ do comprimento do testículo em maturação/ maduro e contém de 41 a 73 franjas e a região caudal representa $40 \%$ e possui de 44 a 68 franjas. Na região cranial o comprimento das franjas é 3,70 $\pm 1,70 \mathrm{~mm}$ e na região caudal $0,20 \pm 0,10 \mathrm{~mm}$. A espermatogênese ocorre de forma sincrônica, em cistos, e em toda a extensão da parede dos túbulos seminíferos. Os ovários são órgãos pares, saculiformes e, histologicamente, apresentam lamelas ovígeras que contém as células da linhagem ovogênica. Os ovócitos foram classificados em quatro fases de desenvolvimento, com base em suas características histológicas e das camadas que os circundam.

PALAVRAS-CHAVE. Espermatogênese, gônadas, morfologia, ovogênese, Pseudopimelodidae.
\end{abstract}

The order Siluriformes is greatly diversified, encompassing morethan 35 families, ca 446 genus and 2867 species (NELSON 2006). The species of this order occurs in the tropical region, especially in South America, Africa and Southeast Asia (DE PINNA 1998). Several species of economic interest such as Pseudoplatystoma coruscans (Spix \& Agassiz, 1829) and P. fasciatum (Linnaeus, 1766) belong to this order. Recently, the morphology of their reproductive system has been studied, in several works that provided basic information to the understanding of the different reproductive strategies, characteristics for phylogenetic analysis, and information to be applied to aquiculture (Brito \& BAZZoli 2003, Romagosa et al. 2003, Batlouni et al. 2006). The family Pseudopimelodidae is only found in South America and is still recognized as one of the less studied families of freshwater Neotropical catfish. Lophiosilurus alexandri Steindachner, 1877 is a sedentary fish, native of the São Francisco river basin, commonly known as "pacamã". It preferentially inhabits lentic environments, reproduces in captivity, has adhesive eggs, the males display parental care and has economic potential for aquiculture (SATO et al. 2003, SHIBATTA 2003). The species was introduced in the Doce river basin and at the present date the effects of this impact under the native species had still not been studied (VIEIRA \& Pompeu 2001).

Some of the families of this order have fringed testis with cells from the spermatic lineage all along their extension; others have seminal vesicles or accessory structures at the caudal region that do not display spermatogenic activity and can store spermatozoa (LEGENDRE et al. 1996). The silurifom Iheringichthys labrosus (Lütken, 1874) has fringed testis with a cranial spermatogenic region, a middle portion both secretory and spermatogenic and a caudal region exclusively secretory (SANTOS et al. 2001). The testis of Loricaria lentiginosa Isbrücker, 1979 are

Revista Brasileira de Zoologia 24 (1): 213-221, março 2007 
not fringed and, at their caudal region, present a diffuse secretory tissue that does not form a conspicuous gland (GUIMARÃESCruz et al. 2005).

In fishes, as in other anamniotes, the unit of spermatogenesis is a spermatocyst, usually referred to as a cyst. The development of the cyst begins when a primary spermatogonium becomes associated with a somatic cell which completely envelopes the germ cell with thin cytoplasmic processes. The primary spermatogonium then divides mitotically to produce a number of secondary spermatogonia. Spermatogonia then enter meiosis to form spermatocytes. During spermatogenesis all germ cells within a cyst are approximately at the same phase of development. The size of the cyst increases due to the maturation of germ cells, development of a lumen, as well as by growth and differentiation of the somatic cells. Following meiosis, spermiogenesis ensues with the formation of spermatids. Finally, a clone of isogenetic spermatozoa are formed (PUDNEY 2003).

The female reproductive system of some Siluriformes species that have been studied is characterized by having paired, elongated ovaries which communicate through theoviduct with the urogenital papillae and are located dorsally in the coelomic cavity (Romagosa et al. 2003, Guimarães-Cruz et al. 2005). The ovaries are surrounded by a capsule made of dense conjunctive tissue that constitutes the tunica albuginea and emits projections to the interior of the organ where it forms the ovigerous lamellae. These lamellae give support to the germ cells during the different stages of their development (BAzzol 2003). There are two main stages during the development of the oocytes in teleosts: the gonadotrophins-independent primary growth, and the secondary growth which is dependent on gonadotrophins (Selman \& W Allace 1989, Tyler \& Sumpter 1996). The perinucleolar stage takes place during the primary growth while the vitellogenesis occurs during the secondary growth (Patiño \& SulLivan 2002). During follicle formation morphologic changes take place in the nucleus, ooplasm, zona radiata and follicular cells (GRIER 2000). In several fish species, after the spawning and during embryonic development, specialized structures present at the oocytes surface can mediate interactions between the eggs and the different substrates where they are deposited (Rızzo et al. 2002). In some Siluriformes, the jelly coat located external to the zona radiata can be related to the adhesiveness of the eggs to the substrate (Rızzo \& GodınHo 2003).

In this study, the morphology of the gonads and the gametogenesis of L. alexandri (Fig. 1) were analyzed using anatomic, morphometric and histological techniques, in order to providebasic information for the comprehension of the species reproduction and the phylogenetic relationships between Siluriformes species.

\section{MATERIAL AND METHODS}

\section{Specimens}

Adults specimens of $\mathrm{L}$. alexandri, comprising 27 males and 16 females, were captured trimonthly at the Santo Antônio River (19009'11"S, 4241'23"W), state of Minas Gerais, southeast Bra- zil (Fig. 2). The fishes were collected between July/2004 and June/ 2005 using gill nets with mesh sizes 8 to $16 \mathrm{~cm}$ (stretched measurement).

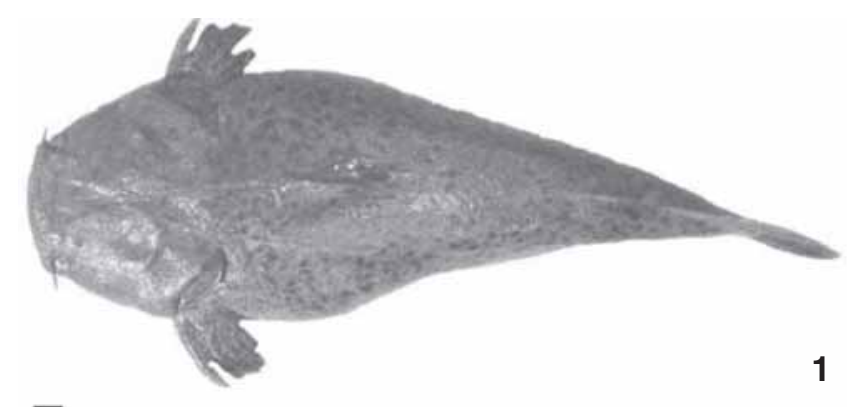

-

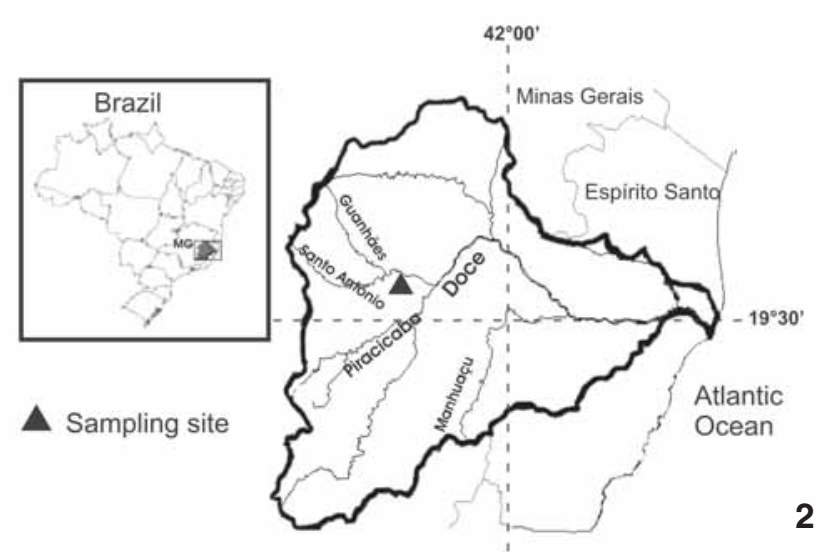

Figures 1-2. (1) Male specimen of Lophiosilurus alexandri Steindachner, 1877, dorsal view. Scale bar $=1.0 \mathrm{~cm}$. (2) Doce river basin, highlighting the sample area at Santo Antônio River.

\section{Anatomy}

Total length $(\mathrm{cm})$ and weight $(\mathrm{g})$ were recorded for each specimen. Gonads (ovaries and testis) were dissected, measured longitudinally (cm) and weighted (g). Results are shown in table I. The testis were divided anatomically in cranial and caudal regions. Twenty maturing/mature testis were fixed in $10 \%$ formaldehyde to be used in the quantification of the number of fringes, and the length of the fringes in both regions (cranial and caudal) was registered using a pachymeter. The mean and standard deviation were calculated.

\section{Light Microscopy}

Whole gonads and fragments of the cranial and caudal portions of testis and ovaries were fixed in Bouin's solution for 8 to 12 hours, embedded in paraffin, cut in 5 to $7 \mathrm{~mm}$ serial sections and stained with hematoxilin-eosin (HE) and Gomori trichrome.

Classical histochemical techniques (PeARSe 1985) were used for the detection of carbohydrates and proteins in the 
Table I. Minimum and maximum values for total lenght ( $T L$ ), body weight (BW), longitudinal length of the gonads (LLG) and gonad weight $(\mathrm{GW})$ in $\mathrm{L}$. alexandri.

\begin{tabular}{lrrrr}
\hline & \multicolumn{2}{c}{ Male } & \multicolumn{2}{c}{ Female } \\
\cline { 2 - 5 } & Minimum & Maximum & Minimum & Maximum \\
\hline TL (cm) & 26.50 & 60.00 & 33.80 & 65.00 \\
BW (g) & 293.00 & 2613.00 & 605.00 & 3500.00 \\
LLG (cm) & 5.10 & 9.70 & 3.70 & 9.00 \\
GW (g) & 0.45 & 4.36 & 0.33 & 61.99 \\
\hline
\end{tabular}

caudal region of the maturing/mature testis: Periodic Acid-Schiff (PAS), Alcian Blue (AB) pH 2.5 and $\mathrm{AB}$ pH 0.5 and NinhydrinSchiff (NS). Ovaries slides containing vitellogenic oocytes were also treated with PAS.

The diameters of 100 nuclei from cells in each stage of the spermatogenic and oogenic lineages were measured using a micrometric rule attached to the ocular of a zeiss light microscopy. The thickness of the zona radiata in previtellogenic and vitellogenic oocytes and the height of the follicular cells in advanced perinucleolar, previtellogenic and vitellogenic oocytes were also measured. The measured cells were selected from 15 histological preparations of ovaries and 15 of testis, taking in account the integrity of the cells (no evidence of retraction). For all the measured structures the mean and standard deviation were calculated.

\section{RESULTS}

\section{Testis Morphology}

The testis are paired organs, fringed in all their extension. Establish anatomical relations with the swim bladder and kidneys dorsally and with the intestine ventrally. No males in resting stage were captured. The maturing/mature testis are whitish, bulky, with turgid and well developed fringes (Fig. 3). Left and right testis join together caudally, and present a compact medial region and a lateral portion constituted by fringes. The fringes communicate with the compact region individually or associated in pairs or triplets.

The cranial region represents ca. $60 \%$ of the testes length, containing 41 to 73 fringes, while the caudal portion represents ca. $40 \%$ and contains 44 to 68 fringes (Fig. 3). At the cranial portion the length of the fringes is $3.70 \pm 1.70 \mathrm{~mm}$ and in the caudal portion is $0.20 \pm 0.10 \mathrm{~mm}$.

The fringes at the cranial region are exclusively spermatogenic (Fig. 4) while in the caudal region spermatogenic and secretory fringes can be found (Fig. 5). The secretion was observed associated with spermatozoa, at the lumen of the tubules and in the common spermatic duct (Fig. 6). This secretion reacts positively to the PAS and NS techniques, indicating the presence of neutral glycoproteins.

The testis are externally coated by a capsule of conjunctive tissue (the al buginea). The al buginea projects to the interior of the organ forming compartments that contain tubules which communicate with the spermatic ducts. The spermatic ducts of the right and left testis are joined at their caudal portion, forming the common spermatic duct that extends to the urogenital papillae, situated caudally to the anal orifice (Figs 3 and 7). The testicular parenchyma is located between the albuginea and the spermatic duct and is formed by seminiferous tubules and interstitial tissue. The seminiferous tubules present a widelumen and an epithelium constituted by cysts, with germ cells in different developmental stages (Fig. 11). The limits of the cysts are defined by cytoplasmic extensions of the Sertoli cells (Fig. 12). The cysts break apart at the end of the spermatogenesis releasing the spermatozoa in the tubules lumen, which anastomosized. The spermatozoa reach the spermatic ducts and then the common spermatic duct, where they are stored until spermiation. The interstitial tissue is constituted by cells and fibres of conjunctive tissue, myoid cells, blood vessels and Leydig's cells (Fig. 13). The Leydig's cells which were observed both isolated or in groups, are rounded, with acidophilic cytoplasm and have a nucleus with diffuse chromatin and conspicuous nucleolus. The wall of the urogenital papillaeisformed by simple prismatic epithelium and a conjunctive-muscular basal lamina (Fig. 7).

\section{Spermatogenic lineage cells (Fig. 11)}

Primary spermatogonia: the largest cell of the lineage, occurring only one per cyst. It has abundant cytoplasm and a spherical central nucleus $(\varnothing=5.78 \pm 0.64 \mu \mathrm{m})$ with an evident nucleolus.

Secondary spermatogonia: they form cysts with two to four cells. They present little cytoplasmic material and a spherical central nucleus ( $\varnothing=4.37 \pm 0.48 \mu \mathrm{m})$ with one or two nucleolus.

Primary spermatocyte: originated from the last generation of secondary spermatogonia after successive mitotic divisions. They present little cytoplasmic content and a spherical central nucleus ( $\varnothing=3.24 \pm 0.74 \mu \mathrm{m}$ ) with granulated chromatin.

Secondary spermatocyte: originated from the first meiotic division of primary spermatocytes. It has little cytoplasmic content and a central spherical nucleus $(\varnothing=2.30 \pm 0.46$ $\mu \mathrm{m})$ with fine chromatin.

Spermatid: it has little cytoplasmic content and a dense spherical nucleus $(\varnothing=1.88 \pm 0.33 \mu \mathrm{m})$.

Spermatozoa: is the smallest of the spermatogenic lineage. It presents a spherical head with little cytoplasmic content and a condensed nucleus $(\varnothing=1.17 \pm 0.38 \mu \mathrm{m})$.

\section{Ovaries morphology}

The ovaries are paired, saculiforms organs (Fig. 8), anatomically related to the swim bladder and kidneys dorsally and with the intestine ventrally. Resting ovaries are whitish, translucent, present few inconspicuous blood vessels, and contain oogonia and perinucleolar oocytes. The maturing/mature ovaries are bulky, yellowish, with oocytes that are visible to the naked eye, have evident vascularization (Fig. 8) and a predominance

Revista Brasileira de Zoologia 24 (1): 213-221, março 2007 

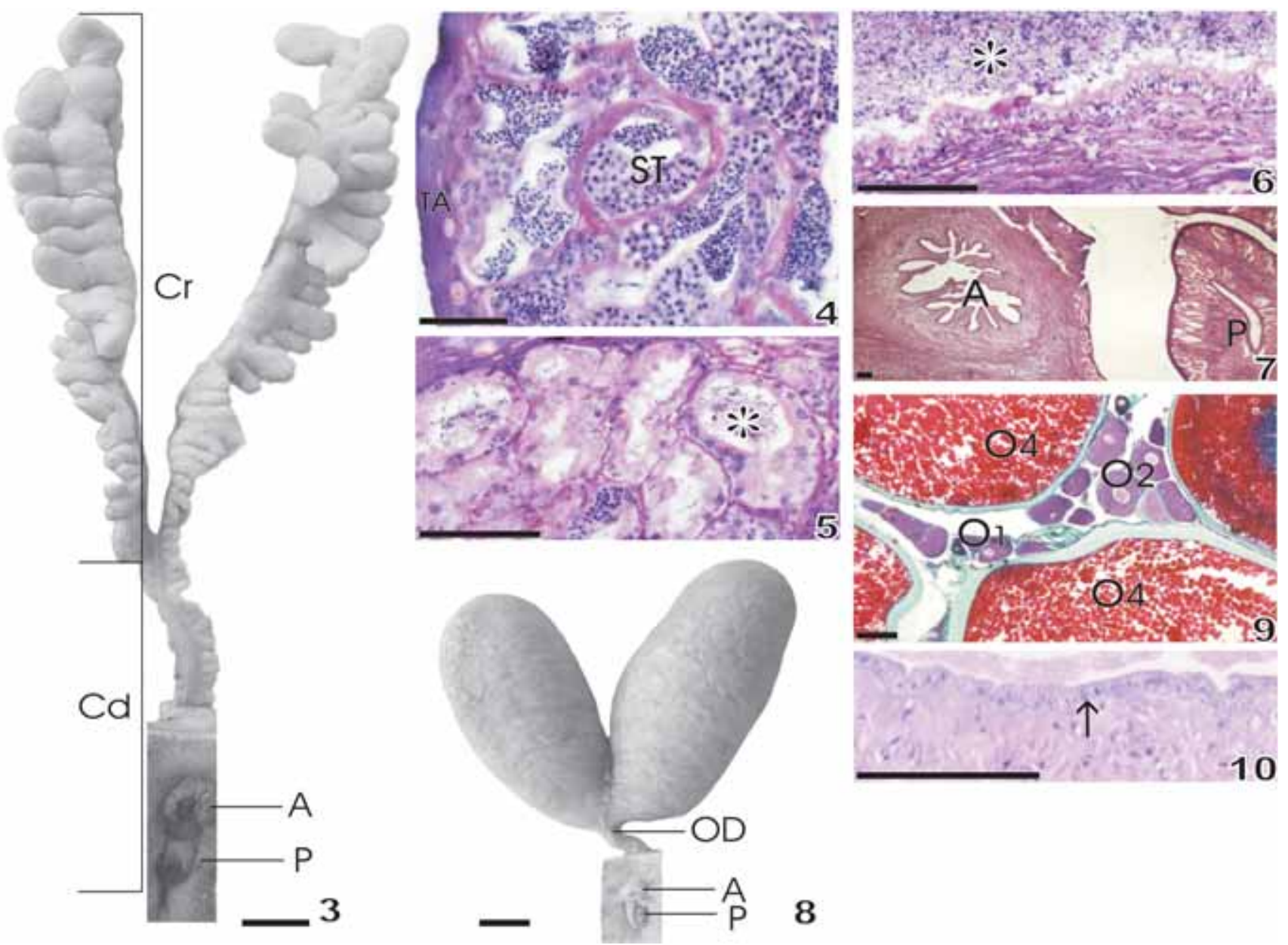

Figures 3-10. Male and female mature reproductive systems: embedded in paraffin and stained with hematoxilin-eosine (Figs 4 to 7 and 10) and Gomori's trichrome (Fig. 9). (3) Fringed testis showing the cranial ( $\mathrm{Cr}$ ) and the caudal (Cd) regions, the anus (A), and the urogenital papillae (P); (4) Cranial region during spermatogenic activity, showing the tunica albuginea (TA), the seminiferous tubules (ST) and cysts of spermatogenic lineage cells in different developmental stages; (5) Caudal region with secretory (*) and spermatogenic activity; (6) Common spermatic duct showing spermatozoa (*) and secretion in the lumen; (7) Transversal section of the urogenital papillae $(P)$ and the anus $(A)$; (8) Maturing ovaries, showing the ovarian duct $(O D)$, the anus $(A)$ and the urogenital papillae $(P)$; $(9)$ Section of the maturing ovary showing the initial perinucleolar oocyte $(\mathrm{O} 1)$, the advanced perinucleolar oocyte (O2) and the vitellogenic oocyte (04); (10) Maturing ovarian duct showing the prismatic epithelium (arrow). Scale bar: Figures 3 and $8=1 \mathrm{~cm}$; Figures 4 to 7, 9 and $10=100 \mu \mathrm{m}$.

of previtellogenic and vitellogenic oocytes (Fig. 9). They are coated with a thick tunica al buginea formed by conjunctive tissue, muscular fibres and blood vessels. Theal buginea sends septa to the lumen forming the ovigerous lamellae where nests of oogonia and oocytes in different developmental stages can be found. Left and right ovaries join at the caudal portion forming the common ovarian duct that communicates with the urogenital papillae (Fig. 8). The wall of the common ovarian duct in maturing/mature ovaries is formed by simple prismatic epithelium resting over a conjunctive tissue layer (Fig. 10).

Revista Brasileira de Zoologia 24 (1): 213-221, março 2007

\section{Oogenic lineage cells (Figs 14-18)}

Oogonia: the smallest cell $(\varnothing=9.08 \pm 0.91 \mu \mathrm{m})$ of the lineage. They are rounded cells found grouped in nests at the ovigerous lamellae. They have little cytoplasmic content, with a nucleus with diffuse chromatin and a unique and prominent nucleolus.

Early perinucleolar oocyte: it has a strongly basophilic cytoplasm with a central nucleus with non-compacted chromatin and several peripheral nucleoli $(\varnothing=108.17 \pm 8.07 \mu \mathrm{m})$. The follicular cells are squamous. 


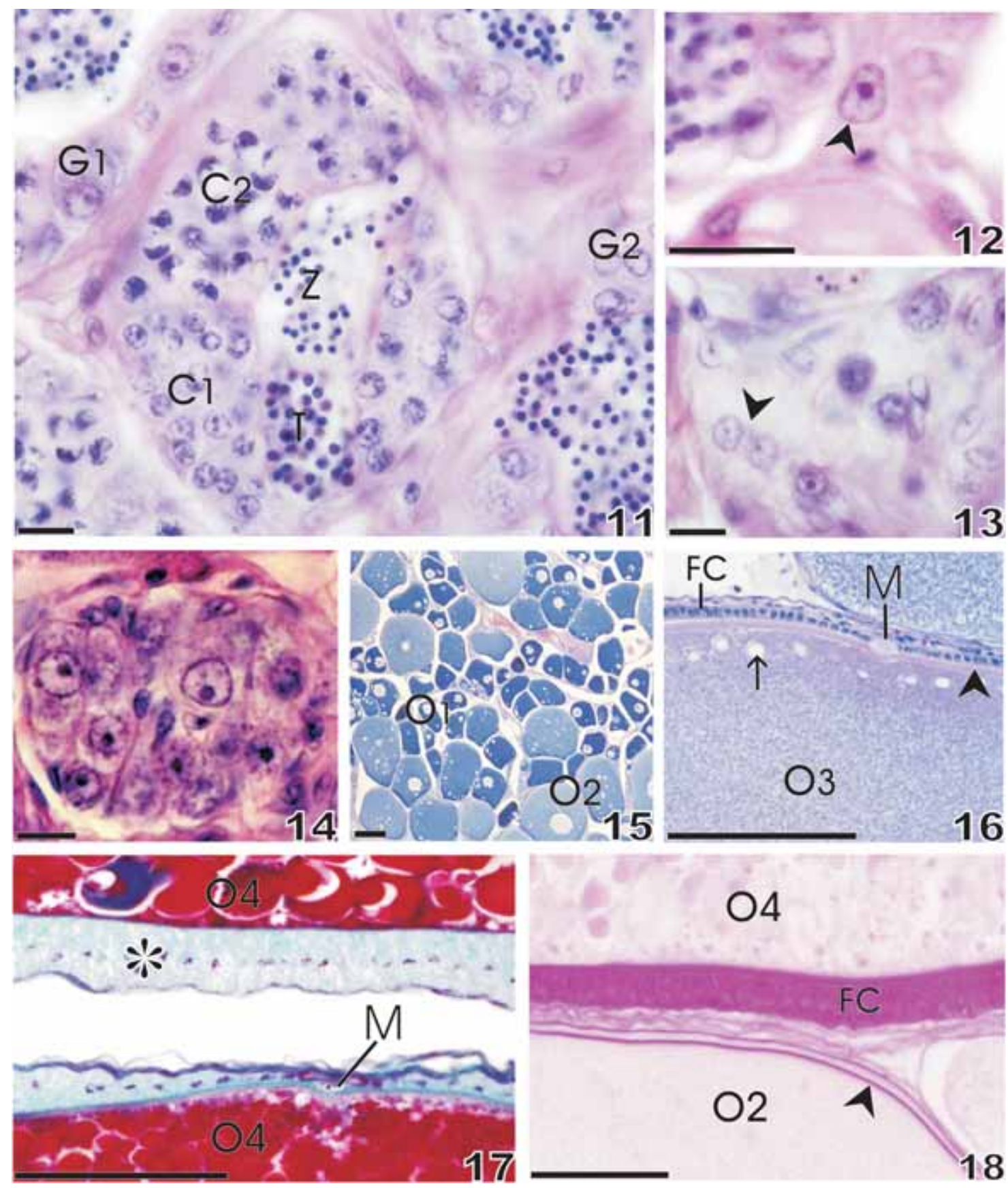

Figures 11-18. Testis and ovaries sections embedded in paraffin and stained with hematoxilin-eosin (Figs 11-16), Gomori trichrome (Fig. 17) and PAS (Fig. 18). (11) Transversal section of a seminiferous tubule showing cysts of the spermatogenic lineage cells: primary spermatogonia (G1), secondary spermatogonias (G2), primary spermatocytes (C1), secondary spermatocytes (C2), spermatids (T) and spermatozoa (Z); (12) Sertoli's cell nucleus (arrow head); (13) Leydig's cell (arrow head); (14) Nest of oogonias; (15) Perinucleolar oocyte in the initial stage (O1) and perinuclear oocyte in the advanced stage (O2); (16) Previtellogenic oocyte (O3) showing the cortical alveolus (arrow), zona radiata (arrow head), cubic follicular cells (FC) and the micropylar cell (M); (17) Vitellogenic oocytes (O4) with prismatic follicular cells (*) and the micropyle region with cubic/squamous follicular cells (M); (18) Advanced perinucleolar oocyte (O2), showing the zona radiata (arrow head) and a vitellogenic oocyte (O4) with prismatic follicular cells (FC), PAS positive. Scale bar: Figures 11 to $14=10 \mu \mathrm{m}$; Figures 15 to $18=100 \mu \mathrm{m}$. 
Advanced perinucleolar oocyte: the cell $(\varnothing=274.40 \pm$ $12.94 \mu \mathrm{m}$ ) has a basophilic finely granulated ooplasm and a nucleus with diffuse chromatin and nucleoli attached to the nuclear membrane. The yolk nucleus is prominent, beginning next to the cellular nucleus and then migrating to the periphery where it disperses. The zona radiata is thin and acidophilic. The micropyle cell closes the micropilar apparatus, which is formed by the vestibule and a short micropylar duct. The follicular cells are squamous with $11.15 \pm 1.25 \mu \mathrm{m}$ height.

Previtellogenic oocyte: the cell $(\varnothing=820.18 \pm 58.23 \mu \mathrm{m})$ basophily of the cytoplasm diminishes gradually and cortical alveoli are formed in the ooplasma periphery. The nucleus is central, with diffuse heterochromatin and the nucleolus attached to the nuclear envelope. The zona radiata is acidophilic and shows $1.59 \pm 0.49 \mu \mathrm{m}$ thickness. The follicular cells are cubic and $18.44 \pm 1.79 \mu \mathrm{m}$ high.

Vitellogenic oocyte: it is the largest cell $(\varnothing=1409.08 \pm$ $72.53 \mu \mathrm{m}$ ) of the lineage, characterized by the presence of acidophilic yolk globules in the ooplasm. The yolk globules at the micropyle region are smaller than other cytoplasmic yolk globules found in the same cell. The zona radiata is $1.35 \pm 0.48 \mu \mathrm{m}$ thick. The follicular cells are prismatic, PAS positive, $30.16 \pm$ $2.71 \mu \mathrm{m}$ high and reduce their height gradually as they become closer to the micropyle.

\section{DISCUSSION}

The anatomical relationships of testis and ovaries of $\mathrm{L}$. alexandri are similar to the ones found in other fresh water Siluriformes that have external fertilization such as P. coruscans (Brito \& Bazzoli 2003) and P. fasciatum (Romagosa et al. 2003, BAtLouni et al. 2006).

The anatomical organization of the testis in Siluriformes has been shown to be variable among the families but the majority of them present fringed testis: Ictaluridae (SNEED \& CLEMENS 1963); Claridae (SIRCAR 1970); Auchenipteridae (MEISNER et al. 2000); Doradidae (Guimarães-Cruz \& Santos 2003); Pimelodidae (Santos et al. 2001, Brito \& Bazzoli 2003, Guimarães-Cruz \& Santos 2004, Lopes et al. 2004, BAtlouni et al. 2006) and Pseudopimelodidae (this study). A study using three different species of Siluriformes showed that the testes length, the total number of fringes and their length presented different values in the caudal and cranial portions (GUImARÃES-Cruz \& SANTOS 2004). The values obtained for $L$. alexandri were also different. The variation of the length between cranial and caudal fringes probably could be explained by their different functions. In the cranial region the fringesincrease in length and diameter by multiplication of spermatogenic lineage cells in the seminiferous tubule walls. Otherwise, the smaller development of the caudal fringes can be explained by the only presence of a secretor epithelium in the tubules wall.

Some families of the order Siluriformes that present fringed testis show secretory activity at their caudal portions, sometimes having a seminal vesicle (LoIr et al. 1989). The cau- dal fringes of the maturing testis of L. alexandri presented tubules internally coated by prismatic, secretory cells, with their lumen filled by secretion and spermatozoa. The chemical nature of the secretion present in the lumen of the tubules in the caudal fringes varies among Siluriformes species. In Pimelodus maculatus La Cepède, 1803 neutral glycoproteins and carboxylated acid glycoconjugates such as sialomucins and sulphated and acid glycoconjugates were detected (Guimarães-Cruz \& SAntos 2004); in I. labrosus (SAntos et al. 2001) and L. alexandri (this work), only neutral glycoproteins were found. This secretion may have similar functions as those exhibited by substances produced in the seminal vesicles of other teleost fishes, containing glycoproteins, steroid hormones and pheromones that can increase the volume of the seminal fluid and can be involved in females attraction and in the fertilization process (LAHNSTEIner et al. 1992, Mazzoldi et al. 2005).

In L. alexandri, the spermatogenic cells are distributed in cysts, all along the extension of the seminiferous tubules, which anastomosis to conduct the spermatozoa to the spermatic ducts, as is characteristic of an anastomosing tubular testes organization (PARENTI \& Grier 2004). The spermatic lineage cells, after several divisions of the primary spermatogonia, acquire thetypical morphology of each developmental stage (BILLARD 1970, Pudney 1993).

In teleosts, including L. alexandri, the cytoplasmic extensions of the Sertoli cells contribute to the formation and sustentation of the cysts, an appropriate place for the differentiation and proliferation in clone germ cells (PUDNEY 1996). In L. alexandri, the breaking of the cystic walls allows the releasing of spermatozoa, as is also the case in species such as I. labrosus (SAntos et al. 2001) and Conorynchus conirostris (Valenciennes, 1840) (Lopes et al. 2004).

The morphology and distribution of Leydig's cells vary with the different vertebrates species (Pudney 1996). They produce steroids that are important for spermatogenesis regulation, the development of secondary sexual characters and reproductive behaviour (WELTZIEN et al. 2004). In L. alexandri, these cells are rounded and were observed isolated or in groups inside the testes stroma.

The morphology of the ovaries of L. alexandri is similar to the morphology of the ovaries of other Siluriformes as P. coruscans (BRITo \& BAzzoli 2003), P. fasciatum (Romagosa et al. 2003), l. labrosus (SAntos et al. 2004) and L. Ientiginosa (GuimarÃes-Cruz et al. 2005). Following HOAR (1969) classification the ovaries of $L$. alexandri are cystovarian, since they present a complete ovarian capsule and an ovarian duct.

In L. alexandri the oogonia were the smallest of the oogenic lineage cells and displayed a morphology similar to the one found in other teleost species studied (GRIER 2000, GUIMARÃES-Cruz et al. 2005). During the primary oocyte growth in L. alexandri the formation of a yolk nucleus and a cortical alveolus was observed. According to BAzolLI \& Godinho (1997), these structures contain neutral glycoproteins that are released 
into the perivitellinic space in order to block polyspermy after fertilization (MICALE et al. 1999). During secondary growth, the oocyte increases its diameter due to the accumulation of yolk (JALABERT 2005). It was observed that the vitellogenic oocytes in L. alexandri increased their diameter in ca. $1.304 \%$ when compared to the initial perinucleolar oocytes size. The vitellogenic oocytes of species such as Danio rerio (Hamilton, 1822) (BECKER

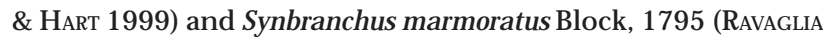
\& MAGGESE 2002) have smaller yolk globules at the periphery and bigger globules at the central region. In L. alexandri it was observed that smaller yolk globules are located only in the micropyle region, possibly to facilitate the displacement of the pronucleus to be fertilized.

The thickness and structure of the zona radiata depend on the species and reflect adaptations to different ecological conditions (FAusto et al. 2004). Siluriformes belonging to the Loricariichthys and Loricaria genus present a thick zona radiata $(9.1 \pm 0.57 \mu \mathrm{m}$ and $9.95 \pm 0.25 \mu \mathrm{m}$, respectively), which might be an adaptation to protect the developing eggs since the males carry them attached to the ventral surface of their bodies in a way that makes the eggs susceptible to physical damage due to contact with the submerse substrates (SUzUKI et al. 2000). On the other hand, L. alexandri presented a thin zona radiata (1.35 $\pm 0.48 \mu \mathrm{m}$ ), which might be explained by the fact of the eggs were not being exposed to physical damage, since they are deposited in nests and incubated by the males. In this study the zona radiata of previtellogenic and vitellogenic oocytes was observed as well as a micropyle apparatus with a wide vestibule and a short micropyle duct, corresponding to a type 1 micropyle in the classification by Ricardo et al. (1996).

The follicular cells originate from the germ epithelium of theovaries, when prefollicular cells emit processes that surround the oocytes during meiosis (GRIER 2000). Quagio-Grassiotto \& GUIMARÃEs (2003) related that the follicular cells of the teleost Serrasalmus spilopleura Kner, 1858 are squamous during the primary growth and become cuboidal during the secondary growth phase, acquiring characteristics typical of proteins or glycoproteins producing cells. The analysis of follicular cells in L. alexandri demonstrated that most of them are squamous during the primary growth and become high-prismatic at the end of the secondary growth, the exception being the cells near the micropyle region that werefound to besquamous/cubic. Thesiluriform Cathorops spixii (Spix \& Agassiz, 1829) presents high follicular cells capable to synthesize the adhesive material that covers the eggs after the spawn and the adhesiveness of the eggs facilitates parental care (FÁvaro et al. 2005). In the siluriform I. labrosus, the follicular cells of vitellogenic oocytes showed secretory activity producing electron-light granules similar to mucosomes, which contain acid glycoconjugates and can be related to the eggs adhesiveness (SAntos et al. 2006). The presence of mucosubstances in the follicular cells of the vitellogenic oocytes of $L$. alexandri was confirmed during this study. These substances can be related with eggs adhesiveness as it has been observed in the siluriform Silurus glanis Linnaeus, 1758 (AвRAHAm et al. 1993). In summary, L. alexandri presents fringed testis with the cranial region being spermatogenic while the caudal region presents both spermatogenic and secretory activities. Testes organization is of the anastomosing tubular type and the spermatogenesis is cystic. The ovaries are of the cystovarian type, the oocytes are adhesive and the follicular cells secrete mucosubstances. All these characteristics are important criteria for phylogenetic analyses among Siluriformes and are use ful for the better comprehension of their reproduction, since this species have a good potential for aquiculture.

\section{ACKNOWLEDGEMENTS}

The authors are grateful to: FIP PUC Minas for financial support (project 2004/17-TLE); the laboratory technicians Rubens Miranda and Rogério S. Matos for preparations of the histological plates, and to RenêE.S. Hojo for the assistance during the collects of the fishes.

\section{REFERENCES}

Abraham, M.; V. Hilge; R. Riehl \& Y. Iger. 1993. Muco-follicle cells of the jelly coat in the oocyte envelope of the sheatfish (Silurus glanis). Journal of Morphology 217: 37-43.

BatlounI, S.R.; E. Romagosa \& M.I. Borella. 2006. The reproductive ciclecatfish Pseudoplatytoma fasciatum (Teleostei: Pimelodidae) revealed by changes of the epithelium: An approach addressed to aquaculture. Animal Reproduction Science 96 (1-2): 116132.

BAZzoLI, N. 2003. Padrões reprodutivos de peixes de interesse comercial na região de Pirapora, p. 291-306. In: H.P. GodinHo \& A.L. Godinho (Eds). Águas, peixes e pescadores do São Francisco das Minas Gerais. Belo Horizonte, PUC Minas, 468p.

Bazzolı, N. \& H.P. GodınHo. 1997. Ovócitos vitelogênicos do surubim Pseudoplatystoma coruscans e do pacamã Lophiosilurus alexandri. Surubim 19: 81-90.

BeCKER, K.A. \& N.H. HART. 1999. Reorganization of filamentous actin and myosin-II in zebrafish eggs correlates temporally and spatially with cortical granule exocytosis. Journal of Cell Science 112: 97-110.

Billard, R. 1970. La spermatogenese de Poecilia reticulata. III. Ultrastructure des cellules de Sertoli. Annales de Biologie Animale Biochirnie Biophysique 10: 37-50.

BrITo, M.F.G. \& N. BAZzoLI. 2003. Reproduction of the surubim catfish (Pisces, Pimelodidae) in the São Francisco river, Pirapora region, Minas Gerais, Brazil. Arquivo Brasileiro de Medicina Veterinária e Zootecnia 55 (5): 624-633.

DE PInnA, M.C.C. 1998. Phylogenetic Relationships of Neotropical Siluriformes (Teleostei: Ostariophysi): Historical Overview and Synthesis of Hypotheses, p. 279-330. In: L.R. MALABARBA; R.E. ReIS; R.P. VARI; Z.M.S. LuCENA \& C.A.S. LuCENA (Eds). Phylogeny and classification of Neotropical fishes. Porto Alegre, EDIPUCRS, III+603p.

Revista Brasileira de Zoologia 24 (1): 213-221, março 2007 
Fávaro L.F.; F.A. Frehse; R.N. Oliveira \& R. Schwarz Júnior. 2005. Reprodução do bagre amarelo, Cathorops spixii (Agassiz) (Siluriformes, Ariidae), da Baía de Pinheiros, região estuarina do litoral do Paraná, Brasil. Revista Brasileira de Zoologia 22 (4): 1022-1029.

Fausto, M.A.; S. Picchietti; A.R. Tadel; C. Zeni; G. Scapigliati; M. MAZZINI \& L. ABELLI. 2004. Formation of the egg envelope of a teleost, Dicentrarchus labrax (L.): immunochemical and cytochemical detection of multiple components. Anatomy and Embryology 208: 43-53.

Grier, H.J. 2000. Ovarian germinal epithelium and folliculogenesis in the common snook, Centropomus undecimalis (Teleostei: Centropomidae). Journal of Morphology 243: 265281.

Guimarães-Cruz, R.J. \& J.E. SAntos. 2003. Organização testicular de Franciscodoras marmoratus (Reinhardt, 1874) e Rhinodoras dorbignyi (Kner, 1855) (Siluriformes: Doradidae). Bios 10 (10): 90-91.

Guimarães-Cruz, R.J. \& J.E. Santos. 2004. Testicular structure of three species of neotropical freshwater pimelodids (Pisces, Pimelodidae). Revista Brasileira de Zoologia 21 (2): 267271.

Guimarães-Cruz, R.J.; J.E. Santos \& G.B. Santos. 2005. Gonadal structure and gametogenesis of Loricaria lentiginosa Isbrücker (Pisces, Teleostei, Siluriformes). Revista Brasileira de Zoologia 22 (3): 556-564.

HOAR, W.S. 1969. Reproduction, p. 1-72. In: W.S. HOAR \& D.J. Randall (Eds). Fish Physiology. London, Academic Press, III +485p.

JALABERT, B. 2005. Particularities of reproduction and oogenesis in teleost fish compared to mammals. Reproduction Nutrition Development 45: 261-279.

Lahnsteiner, F.; M. Seiwal.; R.A. Patzner \& E.A. Ferrero. 1992. The seminal vesicles of the male grass goby, Zosterisessor ophiocephalus (Teleostei, Gobiidae). Zoomorphology 111: 239-248.

Legendre, M.; O. Linhart \& R. BillaRd. 1996. Spawning and management of gametes, fertilized eggs and embryos in Siluroidei. Aquatic Living Resources 9: 59-80.

Loir, M.; C. Cauty; P. Planquette \& P.Y. Bail. 1989. Comparative study of the male reproductive tract in seven families of South-American catfishes. Aquatic Living Resources 2: 4556.

LoPES, D.C.R.; N. BAZZOLI; M.F.G. BRITO \& T.A. M ARIA. 2004. Male reproductivesystem in the South American catfish Conorhynchus conirostris. Journal of Fish Biology 64: 1419-1424.

Mazzoldi, C.; C.W. Petersen \& M.B. Rasotto. 2005. The influence of mating system on seminal vesicle variability among gobies (Teleostei, Gobiidae). Journal of Zoological Systematics \& Evolutionary Research 43 (4): 307-314.

Meisner, A.D.; J.R. BuRns; S.H. Weitzman \& L.R. Malabarba. 2000. Morphology and histology of the male reproductive system in two species of internally inseminating South American catfishes, Trachelyopterus lucenai and T. galeatus (Teleostei: Auchenipteridae). Journal of Morphology 246: 131-141.

Micale, V.; G. Maricchiolo \& L. Genovese. 1999. The reproductive biology of the amberjack, Seriola dumerilli (Risso, 1810). I. Oocyte development in captivity. Aquaculture Research 30: 349-355.

NeLSON, J. 2006. Fishes of the World. New York, Wiley, IV +601p.

Parenti, L.R. \& H.J. Grier. 2004. Evolution and phylogeny of gonad morphology in bony fish. Integrative and Comparative Biology 44: 333-348.

Patiño, R. \& C.V. Sullivan. 2002. Ovarian follicle growth, maturation, and ovulation in teleost fish. Fish Physiology and Biochemistry 26: 57-70.

PearSE, A.G.E. 1985. Histochemistry: theoretical and applied. Edinburgh, Churchill Livingstone, II +1055p.

Pudney, J. 1993. Comparative cytology of the non-mammalian vertebrate Sertoli cell, p. 611-657. In: L.D. RusSELL \& M.D. Griswold (Eds). The Sertoli Cell. Clearwater, Cache River Press, 801p.

Pudney, J. 1996. Comparative cytology of the Leydig cell, p. 97142. In: A. PAyne; M.P. Hardy \& L.D. Russell (Eds). The Leydig Cell. Clearwater, Cache River Press, 801p.

Quagio-Grassiotto, I. \& A.C.D. Guimarães. 2003. Follicular epithelium, theca and egg envelopeformation in Serrasalmus spilopleura (Teleostei, Characiformes, Characidae). Acta Zoologica 84: 121-129.

RavagliA, M.\& M.C. Maggese. 2002. Oogenesis in the swampeel Synbranchus marmoratus (Bloch, 1759) (Teleostei, Synbranchidae). Ovarian anatomy, stages of oocyte development and micropyle structure. Biocell 26 (3): 325-337.

Ricardo, M.C.P.; C.A. Aguiar; E. Rizzo \& N. Bazzolı. 1996. Morfologia da micrópila e da célula micropilar em tel eósteos neotropicais de água doce. Arquivo Brasileiro de Medicina Veterinária e Zootecnia 48 (Supl.1): 17-24.

Rızzo, E. \& H.P. Godinho. 2003. Superfície de ovos de peixes Characiformes e Siluriformes, p. 115-132. In: H.P. GodinHo \& A.L. Godinho (Eds). Águas, peixes e pescadores do São Francisco das Minas Gerais. Belo Horizonte, PUC Minas, 468p.

Rizzo, E.; Y. Sato; B.P. Barreto \& H.P. Godinho. 2002. Adhesiveness and surface patterns of eggs in neotropical freshwater teleosts. Journal of Fish Biology 61: 615-632.

Romagosa, E.; P. Paiva; E.F. Andrade-Talmelli \& H.M. Godinho. 2003. Biologia reprodutiva de fêmeas de cachara, Pseudoplatystoma fasciatum (Teleostei, Siluriformes, Pimelodidae) mantidas em cativeiro. Boletim Instituto de Pesca São Paulo 29 (2): 151-159.

Santos, J.E.; E. Rizzo; N. Bazzoli \& G.B. Santos. 2004. Reproduction of catfish Iheringichthys labrosus (Lütken, 1874) (Pisces, Siluriformes) from Furnas reservoir, Minas Gerais, Brazil. Revista Brasileira de Zoologia 21 (2): 193-200.

Santos, J.E.; N. Bazzoli; E. Rizzo \& G.B. Santos. 2001. Morphofunctional organization of the male reproductive 
system of the catfish Iheringichthys labrosus (Lutken, 1874) (Siluriformes: Pimelodidae). Tissue and Cell 33 (5): 533-540.

Santos, J.E.; G.E. Padilha; O. Boncompagni júnior; G.B. Santos; E. Rizzo \& N. BAzzolı. 2006. Oocyte growth and follicular enve lope development in the catfish Iheringichthys labrosus (Siluriformes: Pimelodidae). Tissue and Cell 38 (5): 303-310.

Sato, Y.; N. Fenerich-Veranı \& H.P. Godinho. 2003. Reprodução induzida de peixes da bacia do São Francisco, p. 275-289. In: H.P. Godinho \& A.L. Godinho (Eds). Águas, peixes e pescadores do São Francisco das Minas Gerais. Belo Horizonte, PUC Minas, 468p.

Selman, K. \& R.A. W AlLACE. 1989. Cellular aspects of oocyte growth in teleosts. Zoological Science 6: 211-231.

ShibattA, O.A. 2003. Pseudopimelodidae (Bumblebee catfishes, dwarf marbled catfishes), p. 401-405. In: R.E. ReIS; S.O. KulLander \& C.J. FerRarisJR (Eds). Checklist of the freshwater fishes of South and Central America. Porto Alegre, EDIPUCRS, 720p.
SIRCAR, A.K. 1970. Morphology of the urogenital system of the siluroid fishes. Journal of Zoology 23: 93-117.

Sneed, K.E. \& H.P. Clemens. 1963. The morphology of the testes and accessory reproductive glands of the catfishes (Ictaluridae). Copeia 4: 606-610.

Suzukı, H.I.; A.A. Agostinho, \& K.O. Winemiller. 2000. Relationship between oocyte morphology and reproductive strategy in Ioricariid catfishes of the Paraná River, Brazil. Journal of Fish Biology 57 (3), 791-807.

TYLER, C.R. \& J.P. SUM PTER. 1996. Oocytegrowth and development in teleosts. Reviews in Fish Biology and Fisheries 6: 287318.

Vieira, F. \& P.S. Pompeu. 2001. Peixamentos: uma alternativa eficiente? Ciência Hoje 30 (175): 28-33.

Weltzien, F.A.; E. Anderson; Ø. Anderson; K. Shalchian-tabrizi \& B. NORBERG. 2004. The brain-pituitary-gonad axis in maleteleosts, with special emphasis on flatfish (Pleuronectiformes). Comparative Biochemistry and Physiology 137: 447-477.

Received in 14.VII.2006; accepted in 08.III.2007. 